\title{
PŮVOD A CHEMICKÉ SLOŽENÍ FLUID POVARISKÉ HYDROTERMÁLNÍ MINERALIZACE NA LOKALITĚ ZLATÝ DŮL U HLUBOČEK (SPODNÍ KARBON NÍZKÉHO JESENÍKU)
}

\author{
Origin and chemical composition of fluids of post-Variscan hydrothermal mineralization \\ at locality Zlatý důl near Hlubočky (Lower Carboniferous of the Nízký Jeseník Upland) \\ Michaela Kotlánová',2, Zdeněk Dolníček ${ }^{2}$ \\ 'Ústav geologických věd, Přirodovědecká fakulta, Masarykova univerzita, Kotlářská 267/2, 611 37, Brno; e-mail: kotlmi@seznam.cz \\ ${ }^{2}$ Katedra geologie, Prírodovědecká fakulta, Univerzita Palackého v Olomouci, 17. listopadu 12, 771 46, Olomouc; \\ e-mail:dolnicek@prfnw.upol.cz
}

(25-11 Hlubočky)

Key words: Lower Carboniferous, Nízký Jeseník, hydrothermal mineralization, fluid inclusions, stable isotopes, crush-leach analyses

\begin{abstract}
Origin and chemical composition of fluids of hydrothermal ore veins at historical deposit Zlatý důl near Hlubočky (Lower Carboniferous of the Nizký Jesenik Upland) were studied using petrography, microthermometry and crush-leach analysis of fluid inclusions and analysis of stable isotopes of oxygen and carbon in carbonates, oxygen in quartz and sulphur in sulphides. Studied mineralization has epithermal and partly mesothermal character $\left(\mathrm{Th}=<50\right.$ to $293{ }^{\circ} \mathrm{C}$ ). The $\mathrm{H}_{2} \mathrm{O}-\mathrm{NaCl}-\mathrm{CaCl}_{2}$ system is mostly enclosed in the primary fluid inclusions in minerals of post-Variscan ore veins. These fluids had low to medium homogenization temperatures (68 to $293{ }^{\circ} \mathrm{C}$ ) and moderate to high salinities (19-27 wt. \% NaCl eq.). In contrast, low to moderate salinity (0-10 wt. \% $\mathrm{NaCl} \mathrm{eq.)}$ fluids of the system $\mathrm{H}_{2} \mathrm{O}-\mathrm{NaCl}-\mathrm{KCl}-\left(\mathrm{MgCl}_{2}-\mathrm{FeCl}_{2}\right)$ with low homogenization temperatures $\left(<50\right.$ to $\left.110^{\circ} \mathrm{C}\right)$ were enclosed in secondary fluid inclusions. The main source of water was probably evaporated seawater for older fluids. The source of carbon was in carbon of the homogenized Earth's crust and partly in carbon of organic matter. Meteoric water is the main source for younger fluids. Origin of sulphur of sulphides is in the surrounding Lower Carboniferous sediments (shales). The high content of $\mathrm{SO}_{4}$ in fluids hosted by Fe-rich dolomite suggests the origin of the fluids in the evaporated Permian basins. Studied older quartz-galena vein is probably Variscan in age. Genetically similar mineralization can be found also at other localities in the Moravo-Silesian Lower Carboniferous (Culm, siliciclastics of the Lower Carboniferous age).
\end{abstract}

Úvod

Lokalita Zlatý důl se nachází v kulmu Nízkého Jeseníku, konkrétně v moravickém souvrství, cca $9 \mathrm{~km}$ sv. od Olomouce. Ve středověku se zde těžily polymetalické $\mathrm{Cu}-\mathrm{Pb}-(\mathrm{Au}$ ?)-(Ag?) rudy, zejména galenit, ze kterého bylo získáváno stř́ibro (Novák - Štěpán 1984). Horninové prostředí v okolí lokality je reprezentováno kulmskými sedimenty (klastika spodního karbonu), převážně jílovými břidlicemi a prachovci, které se stř́idají s polohami drob. Podél potoka Zlatý důl, který je pravostranným př́tokem řeky Bystřice, můžeme nalézt haldičky s úlomky hydrotermální žiloviny. Hlušina žil je křemenná, křemen-karbonátová či karbonátová. Sulfidické minerály jsou zastoupeny hlavně chalkopyritem a galenitem, méně pak sfaleritem a pyritem. Nalezen byl i primární chalkozín (Novotný - Pauliš 2006), anatas (Zimák 1984), baryt a minerály vzácných zemin (synchysit, xenotim a minerály skupiny crandallitu) (Dolníček 2010; Kotlánová 2015). Na žilách ve Zlatém dole byly zjištěny dvě generace křemene. Starší mléčně bílý hrubozrnný křemen tvoří samostatné žíly a z rudních minerálů je na něj vázán pouze galenit. Mladší křemen je našedlý, jemnozrnný až středně zrnitý, uzavírá $\mathrm{v}$ sobě chalkopyrit a další sulfidické minerály. Z karbonátů je hojný dolomitický karbonát, který svým chemickým složením odpovídá dolomitu až Fe-bohatému dolomitu (Zimák - Večeřa 1991; Kotlánová 2015), méně pak kalcit. Hydrotermální mineralizací ze Zlatého dolu se již zabývala řada autorů (např. Dolníček 2010; Dolníček - Filip 2008; Kotlánová - Dolníček 2014; Novotný - Pauliš 2006, 2009; Novotný et al. 2008; Zimák - Večeřa 1991; Zimák et al. 2002). Většina uvedených publikací byla zaměřena hlavně na mineralogii hydrotermálních žil, ovšem o podmínkách vzniku žil, původu a chemickém složení fluid formujících mineralizaci zatím př́liš mnoho poznatkủ nemáme. Zimák et al. (2002) studovali fluidní inkluze v jednom vzorku mladšího křemene ze Zlatého dolu. U primárních inkluzí byly změřeny homogenizační teploty $\mathrm{v}$ rozmezí 114-132 ${ }^{\circ} \mathrm{C}$ a salinita byla okolo $23 \mathrm{hm}$. \% NaCl ekv. Zimák a Večeřa (1991) analyzovali stabilní izotopy síry v sulfidech a uvažují o původu síry v kulmských sedimentech.

\section{Metodika a materiál}

Na haldách ve Zlatém dole byly v letech 2012-2015 odebrány vzorky žiloviny $\mathrm{k}$ následnému studiu. $\mathrm{Z}$ reprezentativních vzorkủ byly vyhotoveny oboustranně leštěné destičky. Mikrotermometrická měření byla provedena na aparatuře Linkam THMSG 600 instalované na polarizačním mikroskopu Olympus BX-51 na Katedře geologie PřF UP v Olomouci. U inkluzí byly měřeny následující parametry: $\mathrm{T}_{f}$ - teplota zamrznutí, $\mathrm{T}_{h}$ - teplota homogenizace, $\mathrm{T}_{\text {mice }}$ - teplota tání posledního krystalku ledu a $\mathrm{T}_{\mathrm{e}}$ - teplota eutektika. Salinita byla vypočítána dle Bodnara (1993). Pro genetické typy fluidních inkluzí byly použity 
následující zkratky: P - primární, PS - pseudosekundární a S - sekundární.

Vzorky křemene a karbonátu, určené pro studium výluhů fluidních inkluzí, byly podrceny na frakci 0,3-1,1 mm a vzorky křemene byly povařeny $\mathrm{v} \mathrm{HNO}_{3}$ a následně $\mathrm{v}$ destilované vodě. Vzorky byly vysušeny a pod binokulárním mikroskopem $\mathrm{z}$ nich byly odseparovány jiné minerální fáze a nečistoty. Odvážené množství ( $1 \mathrm{~g}$ ) bylo odesláno na Montanuniversität do Leobenu, kde následovalo promytí vzorků v deionizované vodě a následné sušení vzorků při teplotě $50{ }^{\circ} \mathrm{C}$. Vysušený vzorek o hmotnosti $1 \mathrm{~g}$ byl poté rozetřen $\mathrm{v}$ achátové misce společně $\mathrm{s} 5 \mathrm{ml}$ deionizované vody. Vzniklá suspenze byla přefiltrována přes $0,2 \mu \mathrm{m}$ nylonový filtr. Filtrát byl analyzován v iontovém chromatografu Dionex DX-500. Detekční limity: $\mathrm{Cl}$ (10 ppb), $\mathrm{Br}(2 \mathrm{ppb}), \mathrm{F}(5 \mathrm{ppb}), \mathrm{I}(0,1 \mathrm{ppb})$ a $\mathrm{SO}_{4}(10 \mathrm{ppb})$. Analýzy provedl prof. W. Prochaska.

Izotopové složení $\mathrm{C}$ a $\mathrm{O}$ v karbonátech a $\mathrm{S}$ galenitů bylo analyzováno v ČGS v Praze na hmotnostním spektrometru Finnigan MAT 251 Mgr. I. Jačkovou. Z karbonátů byl $100 \%$ kyselinou fosforečnou ve vakuu uvolněn $\mathrm{CO}_{2}$. Sulfidy byly ve vakuu oxidovány oxidem měd’natým na $\mathrm{SO}_{2}$ za teploty $800{ }^{\circ} \mathrm{C}$. Jako standardů bylo použito pro uhlík PDB, pro kyslík SMOW a pro síru CDT. Přesnost měření pro kyslík byla $\pm 0,1 \%$, pro uhlík $\pm 0,05 \%$ a pro síru $\pm 0,2$ \%o. Pro výpočet izotopového složení C, O a S fluid byly použity rovnice dle Zheng $(1993,1999)$, Ohmoto Rye (1979) a O'Neila et al. (1969).

Vzorky křemene pro studium izotopů kyslíku byly odseparovány od okolní horniny a jiných minerálních fází. Následně byly vzorky povařeny v $\mathrm{HCl}$ a následně i v $\mathrm{HNO}_{3}$. Následovalo propláchnutí vzorků ve vroucí destilované vodě. Usušené vzorky byly rozetřeny na analytickou jemnost $\mathrm{v}$ achátové misce. Poté byly vzorky odeslány na analýzy na pracoviště izotopové geochemie na univerzitě v Tübingenu. Analýzy byly provedeny dr. H. Taubaldem na hmotnostním spektrometru Finnigan MAT 253. Kyslík se $\mathrm{z}$ křemene uvolňoval fluoračním činidlem $\mathrm{BrF}_{5}$ za teploty $500-650^{\circ} \mathrm{C}$ a následně se redukoval uhlíkem na $\mathrm{CO}_{2}$. Chyba měření je max. $0,1 \%$.

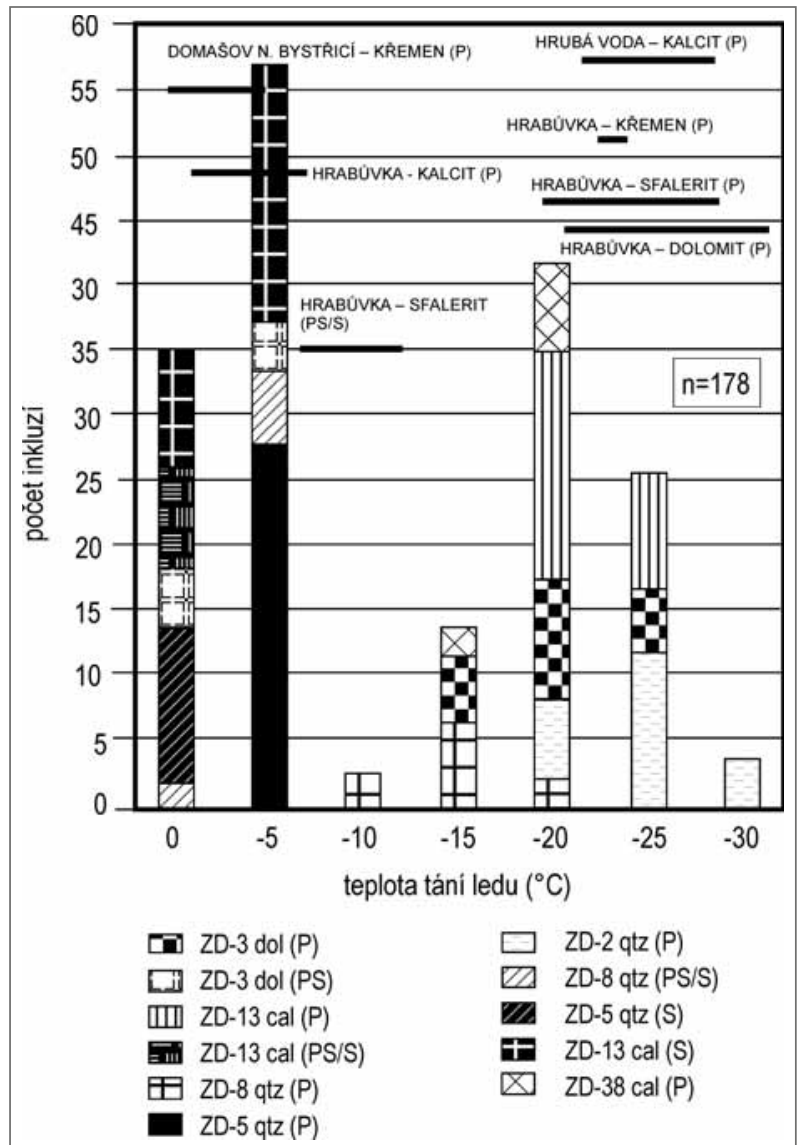

Obr. 1: Graf četnosti naměřených teplot tání posledního krystalu ledu fluidních inkluzí v minerálech povariských rudních žil ze Zlatého dolu a srovnání s dříve publikovanými daty (vodorovné pruhy) pro Hrabůvku (Slobodník - Dolníček 2001), Hrubou Vodu (Dolníček et al. 2003) a ostatní lokality kulmu Nízkého Jeseníku (Kučera 2009).

Fig. 1: Chart of frequency of measured melting temperatures of the last ice crystal in fluid inclusions in minerals from post-Variscan ore veins from Zlatý důl and comparison with previously published data (horizontal bands) for Hrabůvka (Slobodník - Dolníček 2001), Hrubá Voda (Dolníček et al. 2003) and other localities in Culm of the Nízký Jeseník Upland (Kučera 2009).

Tab. 1: Mikrotermometrická data fluidních inkluzí v minerálech rudních žil ze Zlatého dolu.

Tab. 1: Microthermometric data of fluid inclusions in minerals of the ore veins from Zlatý dưl.

\begin{tabular}{|c|c|c|c|c|c|c|c|c|}
\hline Vzorek & Minerál & Geneze & $\begin{array}{c}\text { Fázové složení } \\
\text { (stupeň zaplnění) }\end{array}$ & $\begin{array}{l}\text { Velikost } \\
(\mu \mathrm{m})\end{array}$ & $\mathrm{T}_{\text {mice }}\left({ }^{\circ} \mathrm{C}\right)$ & $\mathrm{T}_{\mathrm{h}}\left({ }^{\circ} \mathrm{C}\right)$ & $\mathrm{T}_{\mathrm{e}}\left({ }^{\circ} \mathrm{C}\right)$ & $\begin{array}{l}\text { Salinita (hm. \% } \\
\quad \mathrm{NaCl} \text { ekv.) }\end{array}$ \\
\hline \multirow{2}{*}{ ZD-3 } & \multirow{2}{*}{$\begin{array}{c}\text { Fe-bohatý } \\
\text { dolomit }\end{array}$} & $\mathrm{P}$ & $\mathrm{L}, \mathrm{L}+\mathrm{V}(0,95)$ & 2 až 7 & $-25,7$ až $-15,8$ & 99 až 138 & $-55,7$ až $-46,8$ & 19,5 až 26,3 \\
\hline & & $\mathrm{PS} / \mathrm{S}$ & $\mathrm{L}+\mathrm{V}(0,95)$ & 2 až 4 & $-4,3$ až $-0,5$ & 49 až 62 & $-22,3$ až $-20,9$ & 1,7 až 6,5 \\
\hline \multirow{2}{*}{ ZD-5 } & \multirow{2}{*}{ Křemen } & $\mathrm{P}$ & $\mathrm{L}+\mathrm{V}(0,70-0,95)$ & 3 až 12 & $-4,1$ až $-7,0$ & 182 až 293 & $-37,1$ až $-36,0$ & 6,5 až 10,5 \\
\hline & & $S$ & $\mathrm{~L}$ & 4 až 7 & $-1,2$ až $-0,7$ & & & 1,5 až 2,0 \\
\hline \multirow{3}{*}{ ZD-8 } & \multirow{3}{*}{ Křemen } & $\mathrm{P}$ & $\mathrm{L}, \mathrm{L}+\mathrm{V}(0,70-0,95)$ & 3 až 20 & $-22,8$ až $-16,2$ & 77 až 134 & $-55,4$ až $-37,8$ & 19,5 až 24,5 \\
\hline & & PS & $\mathrm{L}, \mathrm{L}+\mathrm{V}(0,95)$ & 2 až 5 & $-5,6$ až $-0,8$ & 42 až 68 & $-23,2$ & 1,7 až 9,2 \\
\hline & & S & $\mathrm{L}$ & 2 až 4 & $-4,3$ až $-0,3$ & & $-52,1$ až $-49,0$ & 0,4 až 6,5 \\
\hline ZD-2 & Křemen & $\mathrm{P}$ & $\mathrm{L}, \mathrm{L}+\mathrm{V}(0,95)$ & 3 až 7 & $-26,0$ až $-22,3$ & 99 až 201 & & 24,2 až 26,3 \\
\hline \multirow{3}{*}{ ZD-13 } & \multirow{3}{*}{ Kalcit } & $\mathrm{P}$ & $\mathrm{L}+\mathrm{V}(0,70-0,95)$ & 3 až 8 & $-27,6$ až $-18,4$ & 116 až 139 & $-56,0$ až $-46,8$ & 21,3 až 27,2 \\
\hline & & PS & $\mathrm{L}$ & 4 až 5 & $-0,3$ až 0,0 & & & 0,0 až 0,4 \\
\hline & & $S$ & $\mathrm{~L}, \mathrm{~L}+\mathrm{V}(0,90-0,95)$ & 4 až 8 & $-6,2$ až $-4,5$ & 56 až 110 & $-37,3$ až $-36,8$ & 7,0 až 9,2 \\
\hline ZD-38 & Kalcit & $\mathrm{P}$ & $\mathrm{L}+\mathrm{V}(0,95)$ & 2 až 10 & $-22,1$ až $-16,4$ & 68 až 94 & $-52,1$ až $-43,1$ & 19,5 až 24,2 \\
\hline
\end{tabular}




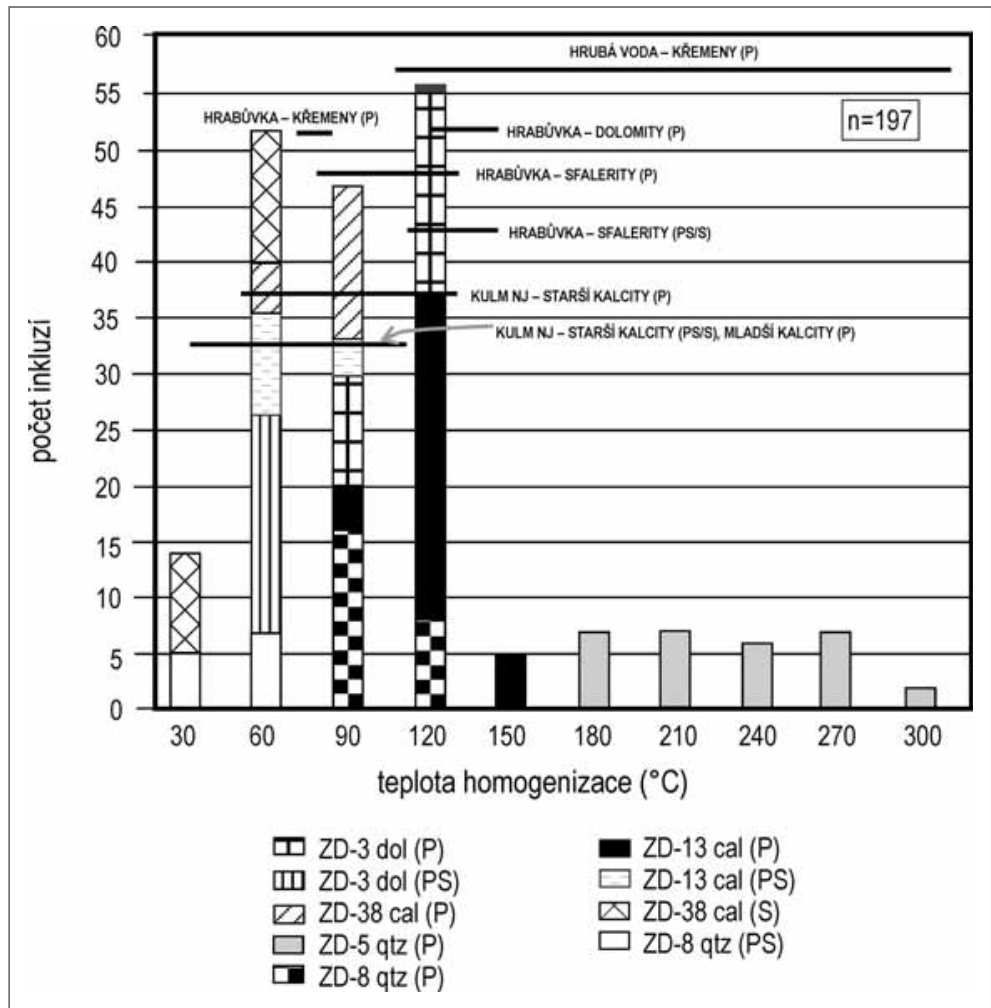

Obr. 2: Graf četnosti naměřených teplot homogenizace fluidních inkluzí v minerálech rudních žil ze Zlatého dolu a srovnání s dř́ve publikovanými daty (vodorovné pruhy) pro Hrabůvku (Slobodník - Dolníček 2001), Hrubou Vodu (Dolníček et al. 2003) a ostatní lokality kulmu Nízkého Jeseníku (Kučera 2009). Fig. 2: Chart of frequency of measured homogenization temperatures of fluid inclusions in minerals from ore veins from Zlatý důl and comparison with previously published data (horizontal bands) for Hrabůvka (Slobodník - Dolníček 2001), Hrubá Voda (Dolníček et al. 2003) and other localities in Culm of the Nízký Jeseník Upland (Kučera 2009).

\section{Petrografie a mikrotermometrie fluidních inkluzí}

Fluidní inkluze byly studovány $\mathrm{v}$ křemenech (vzorky ZD-2, ZD-5, ZD-8), kalcitech (vzorky ZD-13, ZD-38) a dolomitickém karbonátu (vzorek ZD-3) z rudních žil.

$Z$ genetického hlediska převažují u všech vzorků inkluze primární, které nalézáme podél růstových zón či solitérně nebo ve skupinkách po několika inkluzích. Dle fázového složení se jedná o plynokapalné inkluze, obsah plynné fáze je nejčastěji okolo 5 až 10 obj. \%, méně často zaujímá plynná fáze až $30 \mathrm{obj}$ \% (ZD-5). Tvary inkluzí jsou nejčastěji nepravidelné, spíše nahodile i tvaru negativního krystalu. U křemene (ZD-8) byly nalezeny i inkluze ve tvaru kapky. $P$ inkluze dosahují max. velikosti $20 \mu \mathrm{m}$, avšak nejčastěji měřené inkluze měly velikost 4 až $8 \mu \mathrm{m}$. PS i S inkluze jsou nejčastěji jednofázové, kapalné. Méně často jsou dvoufázové, kdy plyn zaujímá okolo 5 obj. \%. Inkluze jsou většinou velmi malé (do $5 \mu \mathrm{m})$ a nejčastěji mají tvar kapky, oválný nebo nepravidelný.

Obsah fluidních inkluzí vymrzá za teplot -33 až $-72{ }^{\circ} \mathrm{C}$. Nejčastěji naměřené teploty eutektika $\left(-56,0\right.$ až $\left.-43,1{ }^{\circ} \mathrm{C}\right)$ indikují, že ve fluidních inkluzích je uzavírán systém $\mathrm{H}_{2} \mathrm{O}-\mathrm{NaCl}-\mathrm{CaCl}_{2}$. U křemene starší generace (ZD-5) byl v primárních inkluzích rozpoznán i systém $\mathrm{H}_{2} \mathrm{O}-\mathrm{NaCl}$ $s$ příměsí $\mathrm{Mg}$ či Fe chloridů ( $\mathrm{T}_{\mathrm{e}} \mathrm{v}$ rozmezí $-37,1$ až $-36,0^{\circ} \mathrm{C}$; Borisenko 1977). Teplota tání posledního krystalku ledu se pohybuje v širokém rozpětí (-27,6 až $0{ }^{\circ} \mathrm{C}$; obr. 1$)$, což odpovídá salinitě 0 až $27,2 \mathrm{hm}$. \% NaCl ekv. V primárních inkluzích ve všech minerálech, vyjma křemene starší generace, jsou nejčastěji uzavírána stř̌edně až výšesalinní fluida. Vysoké salinity byly zjištěny u kalcitu ze vzorku ZD-13 (21,3 až 27,2 hm. \% $\mathrm{NaCl}$ ekv.) a u Fe-bohatého dolomitu ze vzorku ZD-3 (19,5 až 26,3 hm. \% $\mathrm{NaCl}$ ekv.) (tab. 1). Pouze primární inkluze ve starším křemeni uzavírají nízkosalinní fluida (6,5 až 10,5 hm. \% $\mathrm{NaCl}$ ekv.). Nejvy̌šší homogenizační teploty primárních inkluzí byly změřeny u křemene starší generace (ZD-5, 182 až $293{ }^{\circ} \mathrm{C}$ ), nejnižší (68 až $94^{\circ} \mathrm{C}$ ) pak u kalcitu ze vzorku ZD-38 (tab. 1, obr. 2).

V PS a S inkluzích je často uzavírán systém $\mathrm{H}_{2} \mathrm{O}-\mathrm{NaCl}$, $\mathrm{H}_{2} \mathrm{O}-\mathrm{KCl}$ nebo pouze čistá voda. 
Tab. 2: Výsledky analýz izotopového složení kyslíku a uhlíku v karbonátech a kyslíku v křemenech ze Zlatého dolu a vypočtené izotopové složení fluid.

Tab. 2: The results of analysis of isotopic composition of oxygen and carbon in carbonates and oxygen in quartz from Zlatý důl and calculated isotopic compositon of fluids.

\begin{tabular}{|c|c|c|c|c|c|c|}
\hline Vzorek & $\begin{array}{c}\delta^{13} \mathrm{C} \\
\text { (\%o PDB) }\end{array}$ & $\begin{array}{c}\delta^{13} \mathrm{C}_{\text {fluid }} \\
\text { (\%o PDB) }\end{array}$ & $\begin{array}{c}\delta^{18} \mathrm{O} \\
\text { (\%o PDB) }\end{array}$ & $\begin{array}{c}\delta^{18} \mathrm{O} \\
(\% \circ \mathrm{SMOW})\end{array}$ & $\begin{array}{c}\delta^{18} \mathrm{O}_{\text {fluid }} \\
(\% \text { SMOW })\end{array}$ & $\begin{array}{l}\text { Th } \\
\left({ }^{\circ} \mathrm{C}\right)\end{array}$ \\
\hline kalcit (ZD-13) & $-7,9$ & $-11,0$ až $-9,9$ & $-11,9$ & 18,6 & 3,1 až 5,2 & 116 až 139 \\
\hline Fe-bohatý dolomit (ZD-3) & $-1,7$ & $-7,2$ až $-5,0$ & $-17,3$ & 13,1 & $-5,4$ až $-1,3$ & 99 až 138 \\
\hline křemen (ZD-8) & & & & 15,2 & $-9,4 \mathrm{až}-1,8$ & 77 až 134 \\
\hline křemen (ZD-5) & & & & 15,4 & 2,5 až 8,1 & 182 až 295 \\
\hline
\end{tabular}

\section{Chemické složení výluhů fluidních inkluzí} Výluhy fluidních inkluzí byly analyzovány $\mathrm{u}$ tří vzorků - u kř̀emene starší generace (ZD-5), křemene mladší generace (ZD-8) a Fe-bohatého dolomitu (ZD-3). U obou vzorků křemene převažují výrazně chloridy nad

Inkluze jsou často pouze jednofázové a jsou v nich uzavírána nízkosalinní fluida $(0,0$ až 9,2 hm. \% $\mathrm{NaCl}$ ekv.). PS a $S$ inkluze s obsahem plynné fáze homogenizují na kapalinu za teplot 42 až $110^{\circ} \mathrm{C}$. Nejvyšší homogenizační teploty PS/S inkluzí byly naměřeny u kalcitu (ZD-13), nejnižší naopak u křemene mladší generace (ZD-8, tab. 1, obr. 2).

V grafu závislosti teplot homogenizace a salinity fluid (obr. 3) můžeme pozorovat dva vývojové trendy:

1) Vývoj od starších středně teplotních (182 až $\left.293{ }^{\circ} \mathrm{C}\right)$ (pozdně variských?), níže až středně salinních (6 až $10 \mathrm{hm}$. \% $\mathrm{NaCl}$ ekv.) fluid systému $\mathrm{H}_{2} \mathrm{O}-\mathrm{NaCl}$ $\left(\mathrm{FeCl}_{2}-\mathrm{MgCl}_{2}\right)$ v primárních inkluzích u staršího křemene (ZD-5) k nízkoteplotním $\left(<50{ }^{\circ} \mathrm{C}\right)$, nízkosalinním fluidům (okolo $2 \mathrm{hm}$. \% $\mathrm{NaCl}$ ekv.) v sekundárních inkluzích $\mathrm{z}$ téhož vzorku.

2) Vývoj od středně teplotních ( 68 až $201{ }^{\circ} \mathrm{C}$ ), výše salinních (19 až 27 hm. \% $\mathrm{NaCl}$ ekv.) mladších fluid systému $\mathrm{H}_{2} \mathrm{O}-\mathrm{NaCl}-\mathrm{CaCl}_{2}-\left(\mathrm{MgCl}_{2}-\mathrm{FeCl}_{2}\right)$ v primárních inkluzích v kalcitech, křemenech mladší generace a v dolomitickém karbonátu směrem k nízkoteplotním (< 50 až $68{ }^{\circ} \mathrm{C}$ ), nízkosalinním (0 až $9 \mathrm{hm}$. \% $\mathrm{NaCl}$ ekv.) fluidům systému $\mathrm{H}_{2} \mathrm{O}-\mathrm{NaCl}-\left(\mathrm{CaCl}_{2}-\mathrm{KCl}\right)$ v S, případně PS inkluzích v uvedených minerálech.

\section{Izotopové složení S, $\mathrm{C}$ a $\mathrm{O}$}

Bylo studováno izotopové složení síry galenitu starší a mladší generace ze Zlatého dolu. U galenitu starší generace byla naměřena hodnota $\delta^{34} \mathrm{~S}-19,2 \%$ CDT a u galenitu mladší generace byla zjištěna mírně vyšší hodnota $\delta^{34} S$ $-16,8$ \%o CDT. Obdobné hodnoty $\delta^{34}$ S zjistili i Zimák a Večeřa (1991) u dalších sulfidických minerálů ze Zlatého dolu. Zmínění autoři uvádějí hodnoty $\delta^{34} S$ pro pyrity v rozmezí od $-16,6$ do $-19,0 \%$ CDT, pro sfalerity $-17,0$ až $-18,6 \%$ CDT a pro chalkopyrity $-17,0$ až $-18,0 \%$ o CDT.

Analyzováno bylo i izotopové složení uhlíku a kyslíku dvou žilných karbonátů. Nižší hodnota $\delta^{13} \mathrm{C}(-7,9 \%$ \% PDB) byla zjištěna u hrubozrnného kalcitu (ZD-13; tab. 2), přičemž hodnota $\delta^{18} \mathrm{O}$ u téhož vzorku byla vyšší $(18,6 \% 0$ SMOW) oproti dolomitickému karbonátu, u kterého byla hodnota $\delta^{13} \mathrm{C}-1,7 \%$ PDB a hodnota $\delta^{18} \mathrm{O} 13,1 \%$ SMOW. Z těchto naměřených hodnot bylo za použití homogenizačních teplot fluidních inkluzí vypočítáno izotopové složení kyslíku a uhlíku fluid (tab. 2).

Izotopové složení kyslíku žilného křemene bylo studováno u starší a mladší generace křemene ze Zlatého dolu. Starší křemen ze vzorku ZD-5 měl hodnotu $\delta^{18} \mathrm{O}$ 15,4 \% SMOW. U mladšího křemene (ZD-8) byla zjištěna hodnota 15,2 \%o SMOW. ostatními anionty (tab. 3). Pouze u dolomitického karbonátu byl analyzován vyšší obsah síranů $\left(\mathrm{SO}_{4} / \mathrm{Cl}\right.$ je 1,12$)$. $\mathrm{Z}$ kationtů ve všech vzorcích převažuje $\mathrm{Na}$ (tab. 3), méně jsou pak zastoupeny kationty $\mathrm{Ca}, \mathrm{K}$ a $\mathrm{Mg}$.

\section{Diskuze a závěry}

Na lokalitě Zlatý důl byl prokázán vícefázový vznik mineralizace, byly zjištěny dvě generace křemene a galenitu. Ve fluidních inkluzích minerálů povariských rudních žil jsou uzavírána pouze fluida typu $\mathrm{H}_{2} \mathrm{O}$-soli. Dominantními kationty ve fluidech jsou $\mathrm{Na}$ a $\mathrm{Ca}$, méně $\mathrm{K}, \mathrm{Mg}, \mathrm{Fe}$ (?). Z aniontů jsou dominantní chloridy, méně jsou zastoupeny sírany a dusičnany. Starší fluida uzavíraná v primárních inkluzích křemene mladší generace, kalcitech a v dolomitickém karbonátu z povariských žil jsou středněsalinní až vysokosalinní (12 až $27 \mathrm{hm}$. \% NaCl ekv.), níže až středně teplotní ( $\left.\mathrm{T}_{\mathrm{h}}=48 \mathrm{až} 201^{\circ} \mathrm{C}\right)$. Mladší fluida v primárně-sekundárních a sekundárních inkluzích výše uvedených mi-

Tab. 3: Výsledky chemických analýz výluhů fluidních inkluzí v křemenech a Fe-bohatém dolomitu (hodnoty v ppb) a vypočtené molární poměry vybraných iontů a nábojová bilance $\left(\mathrm{Q}^{+} / \mathrm{O}^{-}\right)$. Obsahy $\mathrm{Fe}^{2+}$ dopočteny za předpokladu, že $\mathrm{Q}^{+} / \mathrm{Q}^{-}=1$.

Tab. 3: The results of crush-leach analysis of fluid inclusions in quartz and Fe-rich dolomite (values in ppb) and calculated molar ratios of selected ions and charge balance $\left(\mathrm{Q}^{+} / \mathrm{O}^{-}\right)$. The contents of $\mathrm{Fe}^{2+}$ are calculated on the basis $\mathrm{Q}^{+} / \mathrm{Q}^{-}=1$.

\begin{tabular}{|c|c|c|c|}
\hline Minerál & \multicolumn{2}{|c|}{ křemen } & Fe-bohatý dolomit \\
\hline Vzorek & ZD-8 & ZD-5 & ZD-3 \\
\hline $\mathrm{Li}^{+}$ & 11 & 48 & \\
\hline $\mathrm{Na}^{+}$ & 12913 & 21440 & 3578 \\
\hline $\mathrm{K}^{+}$ & 2056 & 1663 & 616 \\
\hline $\mathrm{Mg}^{2+}$ & 312 & 375 & \\
\hline $\mathrm{Ca}^{2+}$ & 5957 & 7196 & \\
\hline $\mathrm{Fe}^{2+}$ & 1,2 & 1,5 & \\
\hline $\mathrm{F}^{-}$ & 20 & 115 & 284 \\
\hline $\mathrm{Cl}^{-}$ & 31883 & 51341 & 5250 \\
\hline $\mathrm{Br}^{-}$ & 358 & 556 & 49 \\
\hline $\mathrm{I}^{-}$ & 3,7 & 3,5 & 5,1 \\
\hline $\mathrm{NO}_{3}^{-}$ & 4320 & 1108 & 503 \\
\hline $\mathrm{SO}_{4}^{2-}$ & 298 & 433 & 5880 \\
\hline $\mathrm{Br} / \mathrm{Cl} \times 10^{3}$ & 5 & 4,8 & 4,2 \\
\hline $\mathrm{I} / \mathrm{Cl} \times 10^{6}$ & 32 & 19 & 270 \\
\hline $\mathrm{Cl} / \mathrm{Br}$ & 201 & 208 & 240 \\
\hline $\mathrm{K} / \mathrm{Na}$ & 0,09 & 0,05 & 0,1 \\
\hline $\mathrm{Ca} / \mathrm{Na}$ & 0,26 & 0,19 & \\
\hline $\mathrm{Cl} / \mathrm{SO}_{4}$ & 107 & 119 & 0,89 \\
\hline $\mathrm{Q}^{+} / \mathrm{Q}^{-}$ & 0,96 & 0,95 & 0,53 \\
\hline
\end{tabular}




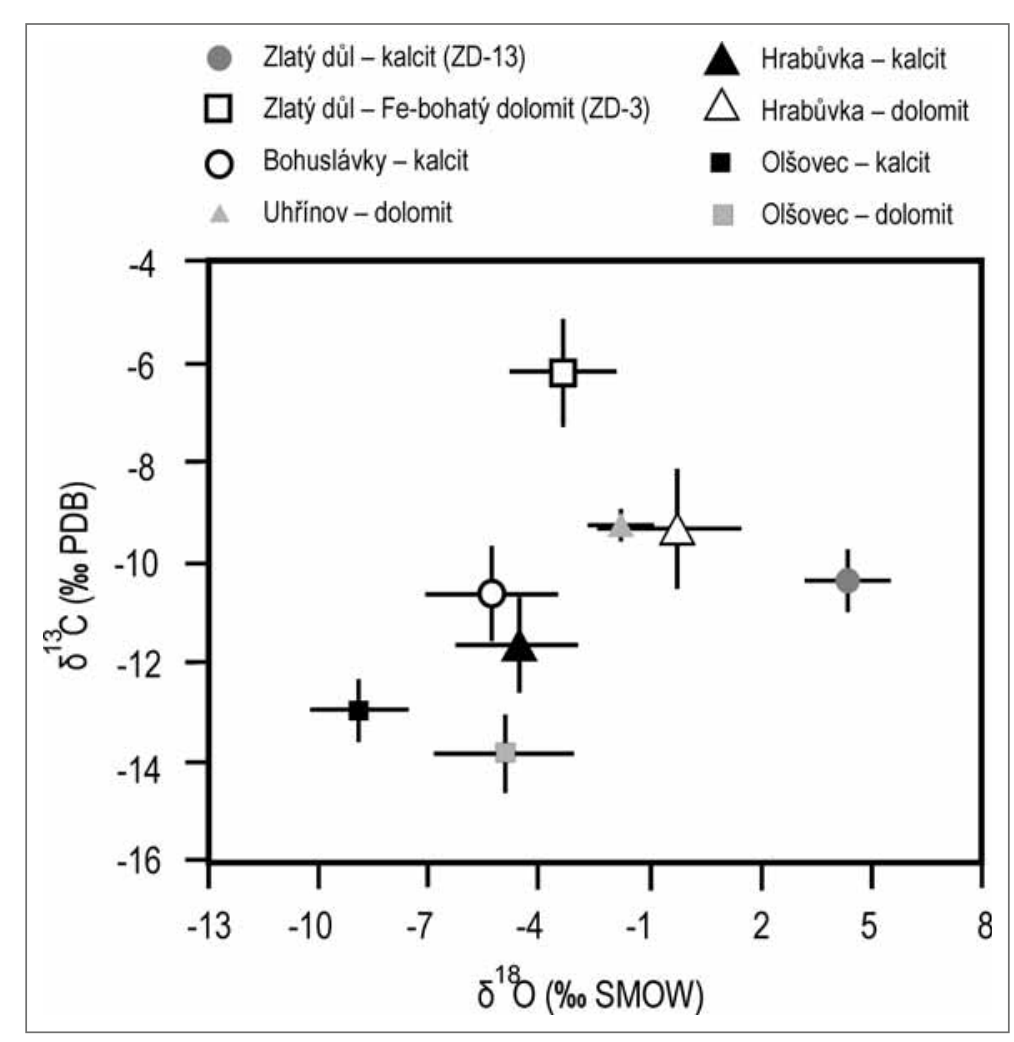

Obr. 4: Graf vypočtených hodnot $\delta^{18} \mathrm{O}$ a $\delta^{13} \mathrm{C}$ hydrotermálních fluid v karbonátech ze Zlatého dolu a z dalších lokalit z kulmu Nízkého Jeseníku (Kotlánová 2015) $\mathrm{V}$ grafu jsou vyneseny průměrné hodnoty $\delta^{18} \mathrm{O}_{\text {fluid }}$ a $\delta^{13} \mathrm{C}_{\text {fluid }}$, čáry značí rozmezí hodnot $\delta^{18} \mathrm{O}_{\text {fluid }}$ a $\delta^{13} \mathrm{C}_{\text {fluid }}$.

Fig. 4: Relationship between calculated $\delta^{18} \mathrm{O}$ and $\delta^{13} \mathrm{C}$ values of the hydrothermal fluids in carbonates from Zlatý důl and other localities from Culm of the Nízký Jeseník Upland (Kotlánová 2015). Data points represent average values of $\delta^{18} \mathrm{O}_{\text {fluid }}$ and $\delta^{13} \mathrm{C}_{\text {fluid }}$, bars represent range of $\delta^{18} \mathrm{O}_{\text {fluid }}$ and $\delta^{13} \mathrm{C}_{\text {fluid }}$ values. nerálů jsou nížesalinní ( 0 až 10 hm. \% NaCl ekv.), nízkoteplotní ( $\mathrm{T}_{\mathrm{h}}=<50$ až $\left.122^{\circ} \mathrm{C}\right)$. Mineralizace s galenitem ze vzorku ZD-5 je pravděpodobně pozdně variského stáří. Teploty homogenizace jsou poměrně vysoké $\left(182-293^{\circ} \mathrm{C}\right)$ a salinita nízká až stř̌ední (7 až 11 hm. \% NaCl ekv.). Obdobnou křemennou mineralizaci s galenitem popisují Dolníček et al. (2003) z nedalekého lomu v Hrubé Vodě. Ovšem homogenizační teploty v křemeni z těchto žil jsou nižší (77 až $154^{\circ} \mathrm{C}$ pro inkluze se stupněm zaplnění 0,95 , u inkluzí s větším obsahem plynu uvažují autoři o homogenizačních teplotách vyšších, pravděpodobně i nad $350^{\circ} \mathrm{C}$, ty však nebyly měřeny). Hodnoty $\delta^{18} \mathrm{O}_{\text {fluid }}$ kalcitu ukazují na zdroj fluid v mořské vodě, u dolomitického karbonátu se výrazněji uplatnila voda meteorická (Hladíková 1988; Hoefs 1997). Vypočtené izotopové složení uhlíku fluid odpovídá uhlíku homogenizované zemské kůry a částečně uhlíku organické hmoty (nejvíce záporné hodnoty u dolomitického karbonátu). Na obrázku 4 vidíme závislost $\delta^{13} \mathrm{C}_{\text {fluid }}$ vs. $\delta^{18} \mathrm{O}_{\text {fluid }} \mathrm{v}$ karbonátech a porovnání s karbonáty z dalších lokalit v kulmu Nízkého Jeseníku. Karbonáty z ostatních lokalit vykazují velmi podobné hodnoty $\delta^{13} \mathrm{C}_{\text {fluid }}$ i $\delta^{18} \mathrm{O}_{\text {fluid }}$. Vypočítané izotopové složení kyslíku fluid křemene (tab. 2) ukazuje na zdroj v meteorické vodě a částečně i ve vodě mořské (Hladíková 1988; Hoefs 1997). Naměřené homogenizační teploty u všech měřených inkluzí s velkou pravděpodobností neodpovídají skutečným teplotám krystalizace minerálů. Uvažujeme-li, že fluidní inkluze byly zachyceny z homogenního fluida, pak skutečné teploty vzniku budou vyšší a vypočítané izotopové složení fluid se bude posouvat směrem ke kladnějším hodnotám. V tomto př́padě je možné uvažovat i o dalším zdroji vyjma mořských a meteorických vod. $\mathrm{V}$ potaz přicházejí magmatické či metamorfní vody. Hoefs (1997) uvádí hodnoty $\delta^{18} \mathrm{O}$ mezi +6 a $+10 \%$ SMOW pro magmatické vody. Pro metamorfní vody jsou typické hodnoty $\delta^{18} \mathrm{O}+5$ až +25\%o SMOW (Taylor 
1974). Vyšší hodnoty $\delta^{18} \mathrm{O}$ fluid mohou také znamenat, že došlo k izotopové výměně kyslíku fluid a hornin za zvýšených teplot (Hoefs 1997). Nicméně hlavním zdrojem fluid v křemenech, kalcitech a Fe-bohatém dolomitu je pravděpodobně mořská voda, ve většině př́ípadů středně až vysoce evaporovaná, která je obsažena zejména ve starších fluidech. Molární poměry $\mathrm{Cl} / \mathrm{Br}$ ve fluidech ze Zlatého dolu (200-240) odpovídají evaporitovým solankám (Labus - Grmela 2004). I vysoké obsahy $\mathrm{SO}_{4}$ ve fluidech $\mathrm{Fe}$ -bohatého dolomitu ze Zlatého dolu podporují názor o původu fluid v kontinentálních evaporovaných jezerech, pravděpodobně permského stárí (Perry - Montgomery 1980; Schreiber et al. 2007). Na formování mineralizace se podílela i voda meteorická, která byla zjištěna dle hodnot $\delta^{18} \mathrm{O}$ ve fluidech mladší mineralizace. Tato fluida jsou převážně nízkosalinní. V grafu $\mathrm{Br} / \mathrm{Cl}$ vs. I/ $\mathrm{Cl}$ (obr. 5) vykazují oba analyzované vzorky křemene shodu s povariskými solankami Českého masivu a taktéž se solankami z kanadského štítu. Pro tyto solanky jsou charakteristické vysoké obsahy $\mathrm{Na}, \mathrm{Ca}$ a $\mathrm{Cl}$ a nízké obsahy $\mathrm{Mg}, \mathrm{K}$ a SO , obsahy Ca jsou většinou vyšší než obsah Na. Tyto solanky odpovídají dle izotopového složení kyslíku evaporované mořské vodě či sedimentárním pánevním solankám (Perry - Montgomery 1980). Poměr I/Cl je u všech vzorků vyšší než u mořské vody (obr. 5). U dolomitického karbonátu (ZD-3) byl poměr I/Cl nejvyšší $\left(270 \times 10^{-6}\right)$. Nárůst obsahu I může být způsoben interakcí s organickou hmotou (Kendrick et al. 2002), která může pocházet $\mathrm{z}$ okolních kulmských břidlic, $\mathrm{s}$ nimiž fluida interagovala. Molární poměry $\mathrm{Cl} / \mathrm{Br}$ jsou poměrně nízké, nejnižší poměr byl analyzován u křemene mladší generace (201), naopak nejvyšší u Fe-bohatého dolomitu (240). Mladší křemen má nejvyšší obsah $\mathrm{NO}_{3}$ (4 320 ppb), kdežto u Fe-bohatého dolomitu byl analyzován obsah nejnižší (503 ppb). Obsahy Li a I jsou ve všech vzorcích velmi nízké (tab. 3), Br a F vykazují také poměrně nízké obsahy, nejvyšší obsah Br byl analyzován u staršího křemene (556 ppb). Nábojová bilance je vyrovnaná u obou vzorkủ křemene $\left(\mathrm{Q}^{+} / \mathrm{Q}^{-}\right.$je 0,95 a 0,96$)$. Hodnoty $\mathrm{Q}^{+} / \mathrm{Q}^{-}$nižší než 1 ukazují na prrítomnost nějakého kationtu, který nebyl analyzován. Při mikrotermometrickém studiu fluidních inkluzí byly relativně často měřeny teploty eutektika od $-36^{\circ} \mathrm{C}$ do $-38^{\circ} \mathrm{C}$, což by mohlo svědčit pro přítomnost $\mathrm{FeCl}_{2} \mathrm{v}$ hydrotermálním roztoku (Borisenko 1977). Vypočítaný obsah $\mathrm{Fe}^{2+}$ ve výluhu (za předpokladu $\mathrm{Q}^{+} / \mathrm{Q}^{-}=1$ ) je však velmi nízký (pouze 1,2 a 1,4 ppb). U dolomitického karbonátu (ZD-3) je $\mathrm{Q}^{+} / \mathrm{Q}^{-}$rovno 0,53 , což je zapř́ičiněno nestanovenými kationty Ca a Mg (jde o hlavní složky, jimiž je tvořena hostitelská minerální fáze a jejich koncentrace ve výluhu je dominantně řízena rozpouštěním minerální fáze). V ternárním diagramu $\mathrm{Cl}-\mathrm{NO}_{3}-\mathrm{SO}_{4}$ pro výluhy fluidních inkluzí (obr. 6) vykazují oba analyzované vzorky křemene shodu s povariskými solankami Českého masivu, částečně také s $\mathrm{Sn}$-W mineralizací z Horního Slavkova. Dolomitický karbonát se odlišuje vyšším obsahem síranů (obr. 6).

Zizotopového složení síry sulfidů můžeme usuzovat na vyloužení síry z okolních kulmských sedimentů - jílových břidlic a prachovců (Hladíková 1988; Hoefs 1997). Zdrojem uhlíku fluid v karbonátech je pravděpodobně uhlík homogenizované zemské kůry nebo hlubinný uhlík. Částečně můžeme hledat zdroj uhlíku i v organické hmotě pocházející ze siliciklastických kulmských sedimentů.

Geneticky obdobné mineralizace jako ve Zlatém dole byly zjištěny i na dalších lokalitách v kulmu Nízkého Jeseníku. Srovnávací data pro mikrotermometrická měření fluidních inkluzí z vybraných lokalit viz obrázky 1 a 2 . Kučera (2009) studoval fluidní inkluze v minerálech hydrotermálních žil v kulmu Nízkého Jeseníku, Drahanské vrchoviny a v hornoslezské pánvi. U dolomitů z kulmu Nízkého Jeseníku zjistil vyšší homogenizační teploty $\left(64-148{ }^{\circ} \mathrm{C}\right)$ 
než u dolomitů $\mathrm{z}$ hornoslezské pánve $\left(67-112^{\circ} \mathrm{C}\right)$. Fluidní systém $\mathrm{H}_{2} \mathrm{O}-\mathrm{NaCl}-\mathrm{CaCl}_{2}$ je podle uvedeného autora nejčastěji uzavírán ve starších fluidech, která jsou vysokosalinní (až 28 hmot. \% NaCl ekv.). V mladších fluidech je uzavřen systém $\mathrm{H}_{2} \mathrm{O}-\mathrm{NaCl}-(\mathrm{KCl})$ nebo jen čistá $\mathrm{H}_{2} \mathrm{O}$ a tato fluida jsou převážně nízkosalinní (do 11 hm. \% NaCl ekv.). U dolomitů a sfaleritů byly naměřeny vyšší homogenizační teploty oproti kalcitům (do $121^{\circ} \mathrm{C}$ ). Původ starších fluid spočívá $\mathrm{v}$ evaporované mořské vodě, jen $\mathrm{s}$ malou př́měsí nízkosalinních meteorických vod, zatímco u mladších fluid se uplatnila více voda meteorická (Kučera 2009).

\section{Poděkování}

Autoři děkují Mgr. I. Jačkové z ČGS v Praze za provedení analýz izotopového složení uhlíku a kyslíku karbonátů a síry sulfidì, prof. W. Prochaskoviz Montanuniversität v Leobenu za provedení analýz výluhư fluidních inkluzí a dr. H. Taubaldovi z Institutu izotopové geochemie na univerzitě v Tübingenu za vyhotovení analýz izotopového složení kyslíku křemene. Laboratorni etapa byla finančně podpořena granty PrF/2014/010 a PrF/2015/014.

Dr. K. Malému a dr. P. Dobešovi děkujeme za recenzní připomínky, které prispěly k vylepšení rukopisu. 


\section{Literatura}

Bodnar, R. J. (1993) Revised equation and table for determining the freezing point depression of $\mathrm{H}_{2} \mathrm{O}-\mathrm{NaCl}$ solutions. - Geochimica et Cosmochimica Acta, 57, 683-684.

Borisenko, A. S. (1977): Izučenije solevogo sostava rastvorov gazovožidkich vklučenij v mineralach metodom kriometrii. - Geologia i Geofizika, 8, 16-27.

Dolníček, Z. (2010): Xenotim-(Y) z rudní žíly na lokalitě Zlatý důl u Hluboček (kulm Nízkého Jeseníku). - Geologické výzkumy na Moravě a ve Slezsku v r. 2009, 17, 133-135. Brno.

Dolníček, Z. - Filip, J. (2008): Dickit z hydrotermální žíly na lokalitě Zlatý důl u Hluboček (kulm Nízkého Jeseníku). - Geologické výzkumy na Moravě a ve Slezsku v r. 2007, 15, 62-64. Brno.

Dolníček, Z. - Fojt, B. - Prochaska, W. - Kučera, J. - Sulovský, P. (2009): Origin of the U-Ni-Co-As-Ag/Bi deposits, Bohemian Massif, Czech Republic: fluid inclusion and stable isotope constraints. - Mineralium Deposita, 44, 81-97.

Dolníček, Z. - René, M. - Hermanová, S. - Prochaska, W. (2014): Origin of the Okrouhlá Radouň episyenite-hosted uranium deposit, Bohemian Massif, Czech Republic: fluid inclusion and stable isotope constraints. - Mineralium Deposita, 49, 4, 409-425.

Dolníček, Z. - Zimák, J. - Slobodník, M. - Malý, K. (2003): Mineralogy and formation conditions of the four types of hydrothermal mineralization from the quarry in Hrubá Voda (Moravo-Silesian Culm). - Acta Universitas Palackiane Olomucensis, Facultas Rerum Naturalium, Geologica, 38, 7-22. Olomouc.

Hladíková, J. (1988): Základy geochemie stabilních izotopů lehkých prvků. - Skripta UJEP Brno, 95 str. Brno.

Hladíková, J. - Kř́íbek, B. (1988): Distribution and isotopic composition of sulphidic sulfur in rocks of the north-eastern part of the Bohemian Massif. - Časopis pro mineralogii a geologii, 33, 2, 113-129.

Hoefs, J. (1997): Stable isotope geochemistry. - Springer Verlag, Berlin-New York, 201 str.

Kendrick, M. A. - Burgess, R. - Pattrick, R. A. D. - Turner, G. (2002): Hydrothermal fluid origins in a fluorite-rich Mississippi Valley-type deposit: Combined noble gas ( $\mathrm{He}, \mathrm{Ar}, \mathrm{Kr})$ and halogen $(\mathrm{Cl}, \mathrm{Br}, \mathrm{I})$ analysis of fluid inclusions from the South Pennine Orefield, United Kingdom. - Economic Geology, 97, 435-451.

Kotlánová, M. (2015): Mineralogie a podmínky vzniku rudních žil z vybraných lokalit jihozápadní ćásti nízkojesenického kulmu. - MS, diplomová práce. Př́rodovědecká fakulta, Univerzita Palackého v Olomouci, 117 str. Olomouc.

Kotlánová, M. - Dolníček, Z. (2014): Bornit z hydrotermální mineralizace historického ložiska Zlatý důl u Hluboček (kulm Nízkého Jeseníku). - Geologické výzkumy na Moravě a ve Slezsku v r. 2013, 21, 1-2, 54-56. Brno.

Kučera, J. (2009): Povariské paleofluidní systémy v karbonských sedimentech moravskoslezského paleozoika. - MS, disertační práce. Př́rodovědecká fakulta Masarykovy univerzity, 90 str. Brno.

Labus, K. - Grmela, A. (2004): Isotopic composition of groundwater in the SW part of the Upper Silesian Coal Basin within territories of Poland and Czech Republic. - Sborník vědeckých Prací Vysoké Školy báňské-Technické Univerzity, Řada hornicko-geologická, 1, 57-68.

Novák, J. - Štěpán, V. (1984): Báňsko-historický výzkum Hrubého Jeseníku a západní části Nízkého Jeseníku ložisek drahých a barevných kovů, 4. Ložisková oblast Ag- $\mathrm{Pb}-\mathrm{Cu}$ rud v povodí řeky Bystřice-Lošov, Velká Bystřice, Hlubočky, Hrubá Voda. - MS, Ústřední ústav geologický, 44 str. Praha.

Novotný, P. - Pauliš, P. (2006): Stř́ibro z Mariánského Údolí a kalciopetersit z Domašova nad Bystřicí. Zprávy Vlastivědného muzea v Olomouci, př́rodní vědy, 285-287, 2-32. Olomouc.

Novotný, P. - Pauliš, P. (2009): Pyromorfit z Hluboček-Mariánského Údolí. - Zprávy Vlastivědného muzea v Olomouci, přírodní vědy, 297, 34-38. Olomouc.

Novotný, P. - Král, J. - Zbirovský, J. (2008): Ověřovací práce v historických důlních dílech v okolí Velké Bystřice. - Zprávy Vlastivědného muzea v Olomouci, 293-295, 58-73. Olomouc.

Ohmoto, H. - Rye, R. O. (1979): Isotopes of sulfur and carbon. Barnes H.L. (ed.) Geochemistry of hydrothermal deposits, $2^{\text {nd }}$ edn. J. Wiley \& Sons, 461-560. New York.

O'Neil, J. R. - Clayton, R. N. - Mayeda, T. K. (1969): Oxygen isotope fractionation in divalent metal carbonates. - Journal of Chemical and Physical Sciences, 51, 5547-5558.

Perry, J. - Montgomery, C. W. (1980): Isotopic studies of hydrologic processes. - Northern Illinois University Press, DeKalb.

Potočková, T. (2013): Mineralogie a podmínky vzniku vybraných zlatonosných mineralizací na Českomoravské vrchovině. - MS, diplomová práce. Př́rodovědecká fakulta, Univerzita Palackého v Olomouci, 90 str. Olomouc.

Schreiber, B. C. - Lugli, S. - Babel, M. (2007): Evaporites through Space and Time. - Geological Society, London, Special Publications, 285, 373 str.

Slobodník, M. - Dolníček, Z. (2001): Základní charakteristika fluid z hydrotermální mineralizace u Hrabůvky, Nízký Jeseník. Geologické výzkumy na Moravě a ve Slezsku v r. 2000, 8, 52-54. Brno.

Taylor, H. P. (1974): The application of oxygen and hydrogen isotope studies to problems of hydrothermal alteration and ore deposition. - Economic Geology, 69, 843-883.

Zheng, Y. F. (1993): Calculation of oxygen isotope fractionation in anhydrous silicate minerals. - Geochimica et Cosmochimica Acta, 57, 1079-1091.

Zheng, Y. F. (1999): Oxygen isotope fractionation in carbonate and sulfate minerals. - Geochemical Journal, 33, $109-126$.

Zimák, J. (1984): Výskyt anatasu na polymetalických rudních žilách v Mariánském Údolí u Olomouce. - Zprávy Krajského Vlastivědného Muzea v Olomouci, 227, 16-18. Olomouc.

Zimák, J. - Večeřa, J. (1991): Mineralogická charakteristika Cu-Pb zrudnění na lokalitě „Zlatý důl“ u Hluboček-Mariánského Údolí u Olomouce. - Acta Universitas Palackiana Olomucensis, Facultas Rerum Naturalium, Geographica-Geologica, 3, 30, 63-74. Olomouc.

Zimák, J. - Losos, Z. - Novotný, P. - Dobeš, P. - Hladíková, J. (2002): Study of vein carbonates and notes to the genesis of the hydrothermal mineralization in the Moravo-Silesian Culm. - Journal of the Czech Geological Society, 47, 3-4, 111-122. Praha. 